University of Chicago Law School

Chicago Unbound

Journal Articles

Faculty Scholarship

2003

\title{
Judge Learned Hand and the Espionage Act of 1917: A Mystery Unraveled
}

Geoffrey R. Stone

Follow this and additional works at: https://chicagounbound.uchicago.edu/journal_articles

Part of the Law Commons

\section{Recommended Citation}

Geoffrey R. Stone, "Judge Learned Hand and the Espionage Act of 1917: A Mystery Unraveled," 70 University of Chicago Law Review 335 (2003).

This Article is brought to you for free and open access by the Faculty Scholarship at Chicago Unbound. It has been accepted for inclusion in Journal Articles by an authorized administrator of Chicago Unbound. For more information, please contact unbound@law.uchicago.edu. 


\title{
Judge Learned Hand and the Espionage Act of 1917: A Mystery Unraveled
}

\author{
Geoffrey R. Stone $\dagger$
}

In his quite brilliant 1917 opinion in Masses Publishing Co v Patten,' Judge Learned Hand set forth a novel interpretation of the Espionage Act of $1917^{2}$ that has had enormous impact on our understanding of the First Amendment. In crafting this opinion, Judge Hand made clear that he was not holding the Act unconstitutional, but was merely construing it against the background of our longstanding commitment to the freedom of speech. Judge Hand adopted this approach in no small measure to deflect the vehemence of what he knew would be a harshly negative reaction to his decision.

As a key step in his analysis, Judge Hand reasoned that-in light of our history, values, and tradition - it would be unwarranted to attribute to Congress an intention to enact a law that would have a broadly suppressive effect on free speech without an unequivocal statement of its purpose to that end. I have always assumed that this was merely a ploy to enable Judge Hand to cast his opinion in terms of statutory construction rather than constitutional compulsion, and that is certainly the conventional wisdom. ${ }^{3}$ On examination, however, it turns out, to my considerable surprise, that Judge Hand was right. Congress did not intend the Espionage Act to have the severely repressive effect attributed to it by the federal courts during World War I. This was a judicial, rather than a legislative, development. This sheds important new light not only on Judge Hand's opinion in Masses, but also on our understanding of Congress, the courts, and their respective roles in the evolution of one of the most repressive periods of American history.

$\dagger \quad$ Harry Kalven, Jr. Distinguished Service Professor of Law, The University of Chicago. I am very grateful to Justin Sandberg, Shana Wallace, Jake Kreilkamp, and Elliot Avidan for their splendid research assistance, to Justice Anthony Kennedy, Bernard Harcourt, Rachel Barkow, Lillian BeVier, Sylvia Law, Deborah Malamud, Richard Pildes, David Strauss, Cass Sunstein, Stephen Schulhofer, and my many colleagues at the University of Chicago and New York University for their helpful suggestions, and to the Harry Kalven, Jr. Memorial Fund for financial support.

1244 F 535 (SD NY 1917), revd, 246 F 24 (2d Cir 1917).

240 Stat 217, 219.

3 See, for example, David M. Rabban, Free Speech in Its Forgotten Years 265 (Cambridge 1997) ("[T]he legislative history of the Espionage Act, which Hand never cited in his opinion, demonstrates the congressional intent to punish the very kind of antiwar material that prompted the postmaster to declare The Masses 'nonmailable."'). 


\section{THE ESPIONAGE ACT OF 1917}

For 120 years, from the expiration of the Sedition Act of 1798 until our entry into World War I, the United States had no federal legislation against seditious expression. ${ }^{4}$ As the nation moved closer to entering the war in Europe, however, Wilson administration officials increasingly expressed concern that they "had no laws adequate to deal with the insidious methods of internal hostile activities." Attorney General Thomas Gregory argued that the government needed to devise new ways to restrict "warfare by propaganda," and as early as 1916, in his third annual message to Congress, President Wilson "cited the need for legislation to suppress disloyal activities."'

The next day, the cabinet asked Attorney General Gregory to prepare new legislation. The legislation, which was drafted by Assistant Attorney General Charles Warren, was presented to Congress in mid-1916, but was not acted upon until Congress declared war a year later. $^{8}$

The Espionage Act of 1917 was directed primarily toward such matters as espionage and the protection of military secrets. Several provisions, however, were relevant to the freedom of speech. Section 3 of Title I of the Act made it a crime, when the nation is at war, for any person willfully to "make or convey false reports or false statements with intent to interfere" with the military success of the United States or "to promote the success of its enemies"; willfully to "cause or attempt to cause insubordination, disloyalty, mutiny, or refusal of duty, in the military or naval forces of the United States"; or willfully to "obstruct the recruiting or enlistment service of the United States." Violations were punishable by prison sentences of up to twenty years." The Act also authorized the Postmaster General to exclude from the mails any writing or publication that is "in violation of any of the provisions of this act" or that contains "any matter advocating or urging

4 See John Lord O'Brian, Civil Liberty in War Time, 42 Rep NY St Bar Assn 275, 279 (1919) ("[T]his country, prior to our entry into the war, had on the statute books almost no protection against hostile activities.").

5 John Lord O'Brian, New Encroachments on Individual Freedom, 66 Harv L Rev 1, 8 (1952). See also Rabban, Free Speech in Its Forgotten Years at 249-50 (cited in note 3) (stating that lawyers in the Department of Justice "became concerned that existing federal laws would be insufficient" to prevent seditious behavior during wartime).

6 See Department of Justice, Annual Report of the Attorney General of the United States for the Year 1918 16-17 (GPO 1918).

7 Paul L. Murphy, World War I and the Origin of Civil Liberties in the United States 53 (Norton 1979). See also Woodrow Wilson's Third Annual Message to Congress, quoted in David M. Kennedy, Over Here: The First World War and American Society 24 (Oxford 1980).

8 See Murphy, World War I and the Origin of Civil Liberties at 54-55 (cited in note 7) (discussing how the espionage bill passed the Senate prior to the nation's entry into war but was not voted on by the House until after).

9 Espionage Act of 1917, 40 Stat at 219. 
treason, insurrection or forcible resistance to any law of the United States." 10

John Lord O'Brian, the Head of the War Emergency Division of the Department of Justice, observed shortly after the war ended that "immense pressure" was "brought to bear throughout the war on the Department of Justice in all parts of the country for indiscriminate prosecution" of dissenters and for "wholesale repression and restraint of public opinion." It was, he added, in this "atmosphere" of passion, patriotism, and clamor that the laws "affecting 'free speech' received the severest test thus far placed upon them in our history." partment of Justice invoked the Espionage Act of 1917 to prosecute more than two thousand dissenters during the war for allegedly disloyal, seditious, or incendiary speech. ${ }^{13}$

The prevailing approach in the lower federal courts to interpreting the Act is well-illustrated by the decision of the United States Court of Appeals for the Ninth Circuit in Shaffer $v$ United States. ${ }^{14}$ In Shaffer, the defendant was charged with possessing and mailing copies of a book, The Finished Mystery, in violation of the Act. The book contained the following passage, which was specified in the indictment:

Standing opposite to these Satan has placed ... a certain delusion which is best described by the word patriotism, but which is in reality murder, the spirit of the very devil.... If you say it is a war of defense against wanton and intolerable aggression, I must reply that ... it has yet to be proved that Germany has any intention or desire of attacking us. . . The war itself is wrong. Its prosecution will be a crime. There is not a question raised, an issue involved, a cause at stake, which is worth the life of one bluejacket on the sea or one khaki-coat in the trenches.

Shaffer was convicted, and the court of appeals affirmed, with the following reasoning:

10 Id at 230.

11 O'Brian, 42 Rep NY St Bar Assn at 306 (cited in note 4).

12 Id at 299.

13 See Rabban, Free Speech in Its Forgotten Years at 256 (cited in note 3) ("Of the approximately two thousand Espionage Act prosecutions, the overwhelming majority were brought and won under title I, section 3."); Murphy, World War I and the Origin of Civil Liberties at 80 (cited in note 7); Department of Justice, Annual Report of the Attorney General at 47 (cited in note 6) ("The number of cases brought under [title I, section 3] exceeds the number of those brought under any other of the war laws, except the selective-service act."). Approximately one thousand individuals were convicted. Murphy, World War I and the Origin of Civil Liberties at 80 (cited in note 7 ).

14255 F 886 (9th Cir 1919).

15 Id at 887. 
It is true that disapproval of the war and the advocacy of peace are not crimes under the Espionage Act; but the question here ... is whether the natural and probable tendency and effect of the words ... . are such as are calculated to produce the result condemned by the statute....

Printed matter may tend to obstruct the ... service even if it contains no mention of recruiting or enlistment, and no reference to the military service of the United States. ...

To teach that patriotism is murder and the spirit of the devil, and that the war against Germany was wrong and its prosecution a crime, is to weaken patriotism and the purpose to enlist or to render military service in the war....

It is argued that the evidence fails to show that [Shaffer] committed the act willfully and intentionally. But ... [h]e must be presumed to have intended the natural and probable consequences of what he knowingly did. ${ }^{16}$

This approach was embraced by almost every federal court that interpreted the Espionage Act during the course of the war. ${ }^{17}$ Judges routinely allowed juries to decide whether a defendant's speech violated the Act, and juries routinely returned a verdict of guilty. ${ }^{18}$ Consider the following:

16 Id at $888-89$.

17 See, for example, Goldstein v United States, 258 F 908, 910-11 (9th Cir 1919) (affirming the conviction of a movie director for presenting a historical film that portrayed soldiers from Britain-a World War I ally-killing women and children during the Revolutionary War); Coldwell $v$ United States, 256 F 805, 810-11 (1st Cir 1919) (affirming the conviction of a public speaker for declaring that three convicted draft-dodgers were "victims of a damnable system of government"); Kirchner v United States, 255 F 301, 303-04 (4th Cir 1918) (affirming the conviction of a public speaker for stating that the United States government was corrupt, the Select Service Act was unconstitutional, and people should not purchase United States bonds); Deason v United States, 254 F 259, 261-62 (5th Cir 1918) (affirming the conviction of a man for making threats to members of a local exemption board in order to have his classification changed); Doe v United States, 253 F 903, 906-07 (8th Cir 1918) (affirming the conviction of the author and mailer of a circular stating that Germany had not made or broken a promise to end U-boat warfare as reported by President Wilson and Secretary of State Lansing); O'Hare v United States, $253 \mathrm{~F} 538$, 539-40 (8th Cir 1918) (affirming the conviction of a "professional Socialist lecturer" for stating that men who enlisted in the army would be "used for fertilizer"); Masses Publishing Co $v$ Patten, 246 F 24, 38-39 (2d Cir 1917) (reversing Judge Hand's opinion); United States v Nagler, 252 F 217, 222-23 (WD Wis 1918) (convicting a man for declaring the Y.M.C.A., the Y.W.C.A., and the Red Cross "a bunch of grafters," in reference to their actions during World War I); United States $v$ Motion Picture Film "The Spirit of '76", 252 F 946, 948-49 (SD Cal 1917) (enjoining the presentation of a film depicting British soldiers killing women and children). For additional citations, see Rabban, Free Speech in Its Forgotten Years at 256-61 (cited in note 3).

18 See Rabban, Free Speech in Its Forgotten Years at 257 (cited in note 3) ("Whatever the offending language, surrounding circumstances, or jury instructions, almost all prosecutions led to guilty verdicts."). 
- Rose Pastor Stokes, a Russian immigrant who had worked as a cigarmaker for twelve years before becoming editor of the socialist Jewish Daily News, was convicted and sentenced to ten years in prison for saying, "I am for the people and the government is for the profiteers," during an antiwar statement to the Women's Dining Club of Kansas City. Her speech was later published in the Kansas City Star. Although there were no soldiers-indeed, no men-in her intended audience, the government nonetheless argued that she had violated the Act because "our armies ... can operate and succeed only so far as they are supported and maintained by the folks at home," and Stokes's statement had the tendency to "chill enthusiasm, extinguish confidence, and retard cooperation" of mothers, sisters, and sweethearts."

- J.P. Doe, the son of a Chief Justice of the Supreme Court of New Hampshire, was convicted for mailing an "endless chain" letter to "friends of immediate peace" stating that Germany had not broken a promise to end submarine warfare. Although this was clearly a matter of historical interpretation and opinion, the government argued that Doe had violated the Act because the suggestion that the United States was unjustified in relying on the breach of promise as a cause for our entry into the war "would have a direct tendency to obstruct the recruiting and enlistment service. ${ }^{20}$

- D.T. Blodgett was sentenced to twenty years in prison for circulating a leaflet urging voters in Iowa not to reelect a congressman who had voted for conscription and arguing that the war served the interests of capitalists. The trial judge observed that "there is no better means of unsettling the confidence of the people and stirring their souls against the war than to paint it as a

19 United States v Stokes, (unreported) (D Mo 1918), revd, 264 F 18 (8th Cir 1920), quoted in Zechariah Chafee, Jr., Free Speech in the United States 52-53 (Harvard 1948). See also H.C. Peterson and Gilbert C. Fite, Opponents of War 185-86 (Wisconsin 1957); Mrs. Rose P. Stokes Convicted of Disloyalty; Illegal to Impair National Morale, Says Judge, NY Times 1 (May 24, 1918); Mrs. Stokes Denies Assailing Red Cross, NY Times 5 (May 22, 1918) (reporting Stokes's statements during her trial); Mrs. Stokes Denies Disloyal Intent, NY Times 13 (May 23, 1918) (reporting the conclusion of Stokes's trial and summation arguments by both attorneys). On March 9,1920 , a federal court of appeals overturned Stokes's conviction, ruling that that district judge had placed "too heavy a burden" on the defendant because of his inappropriate "patriotic zeal." Stokes, $264 \mathrm{~F}$ at 26. See also Ten-Year Sentence of Mrs. Rose Stokes Overruled by Federal Court in St. Louis, NY Times 1 (Mar 10, 1920). On November 15, 1921, the government finally dismissed the charges against Stokes. See Mrs. Stokes Freed; Debs May Soon Be, NY Times 5 (Nov 16, 1921) (reporting that the U.S. Attorney General's office had requested the dismissal of charges).

20 United States $v$ Doe, (unreported) (D Colo 1918), affd, 253 F 903 (8th Cir 1918), quoted in Chafee, Free Speech in the United States at 54-55 (cited in note 19). 
war of capitalism ... and painting the officers of this government as ... willing tools of Wall Street.,"21

- Thirty German-Americans in South Dakota were arrested for sending a petition to the Governor demanding reforms in the selective service procedure. The signers of the petition "threatened" to vote the Governor out of office if he did not meet their demands. The government charged that the defendants had willfully obstructed the recruiting and enlistment service.

- The Reverend Clarence H. Waldron was convicted for distributing a pamphlet stating that "if Christians [are] forbidden to fight to preserve the Person of their Lord and Master, they may not fight to preserve themselves, or any city they should happen to dwell in." The government charged that Waldron had attempted to cause insubordination and to obstruct the recruiting service. He was sentenced to fifteen years in prison. ${ }^{23}$

- Robert Goldstein was convicted for producing a motion picture about the American Revolution. "The Spirit of '76" depicted Paul Revere's ride, the signing of the Declaration of Independence, and Washington at Valley Forge. But it also included a scene portraying the Wyoming Valley Massacre, in which British soldiers were depicted bayoneting women and children. The government charged that this was an attempt to promote insubordination be-

21 United States v Blodgett, (unreported) (SD Iowa 1918), quoted in Walter Nelles, ed, Espionage Act Cases with Certain Others on Related Points 48, 52 (National Civil Liberties Bureau 1918).

22 See 30 Germans are Arrested in South Dakota for Opposing the War and the Draft Law, NY Times 1 (Aug 28,1917) (reporting that the men were charged with "having signed a petition of an intimidating character"). While the defendants' appeal was pending in the Supreme Court, the government offered a "confession of error." See Baltzer v United States, 248 US 593, 593 (1918). For a full discussion of this prosecution, including Justice Holmes's unpublished opinion in the case, see Sheldon M. Novick, The Unrevised Holmes and Freedom of Expression, 1991 Sup Ct Rev 303, 331-35, 388.

23 United States $v$ Waldron, (unreported) (D Vt 1918), quoted in Chafee, Free Speech in the United States at 55-56 (cited in note 19). The government was especially aggressive in its prosecution of clergymen who supported peace or conscientious objection. See Warn Seditious Pastors, NY Times 16 (Mar 31, 1918):

Disloyalty fostered by certain religious sects has been growing in the United States ... according to Department of Justice officials. ... [The government] regards the preaching of opposition to the aims of this particular war as of seditious nature. Several German and Austrian preachers and Sunday school teachers have been indicted for disloyal utterances, and many others ... have been warned to desist from criticising the nation's war motives.

Special Assistant Attorney General John Lord O'Brian declared that "the most dangerous type of propaganda ... is religious pacifism, i.e., opposition to the war on the ground that it is opposed to the word of God." Letter from John Lord O'Brian to Rep Edwin Y. Webb, in 65th Cong, 2d Sess (Apr 16, 1918), in 56 Cong Rec S 5542 (Apr 24, 1918). 
cause of its negative portrayal of our ally in the war against Germany. In upholding the seizure of the film, the trial judge explained, "History is history, and fact is fact. There is no doubt about that." But, he added, "this is no time" for "those things that may have the tendency ... of creating animosity or want of confidence between us and our allies." Goldstein was sentenced to ten years in prison. ${ }^{24}$

In the hands of the Department of Justice and the federal judiciary, the Espionage Act thus became an efficient tool for the suppression of "disloyal utterances." As Professor Zechariah Chafee concluded, under the "bad tendency" interpretation of the Act, "[a]ll genuine discussion among civilians of the justice and wisdom of continuing a war ... becomes perilous." ${ }^{25}$ It was against this background that Judge Hand decided Masses.

\section{MASSES}

The Masses was a monthly "revolutionary" journal that regularly featured "a remarkable group" of authors, including Max Eastman, Vachel Lindsay, John Reed, Bertrand Russell, Carl Sandburg, Louis Untermeyer, and Sherwood Anderson. The Masses was iconoclastic, impertinent, and confrontational. It was an "unusually handsome" journal, "with bright-colored covers and oversize pages filled with bold drawings and lively social satire, political criticism, and intellectual commentary." Irving Howe described The Masses as "a combination of Circus, nursery, and boxing ring-for almost everything that was then alive and irreverent in American culture," and Floyd Dell proclaimed that The Masses stood for "fun, truth, beauty, realism, freedom, peace, feminism, revolution." Collectively owned and governed, The Masses was "not so much a publishing venture as a movement, ... a way of life.",

24 "The Spirit of '76", $252 \mathrm{~F}$ at $947-48$ (SD Cal 1917) (confiscating the film and prohibiting its presentation without modification). See Peterson and Fite, Opponents of War at 185-86 (cited in note 19). The movie was finally screened at Town Hall in New York City in July of 1921. See Revive 'Spirit of '76,' Film Barred in 1917, NY Times 18 (July 14, 1921).

One of the most extreme of the Espionage Act prosecutions was that of Walter Matthey of Iowa, who, according to Attorney General Gregory, was sentenced to a year in jail for "attending a meeting, listening to an address in which disloyal utterances were made, applauding some of the [disloyal] statements made by the speaker ... and contributing 25ф." See Robert Justin Goldstein, Political Repression in Modern America: From 1870 to the Present 114 (Schenkman 1978).

25 Chafee, Free Speech in the United States at 51-52 (cited in note 19).

26 Gerald Gunther, Learned Hand 153 (Knopf 1994) (describing the character of The Masses and detailing its beginnings).

27 William O'Neill, The Last Romantic: A Life of Max Eastman 40 (Oxford 1978) (quoting Irving Howe and Floyd Dell).

28 Id at 34. See also Sylvia A. Law, Crystal Eastman: Organizer for Women's Rights, Peace and Civil Liberties in the 1910s, 28 Valp U L Rev 1305 (1994). 
In the summer of 1917, Postmaster General Burleson ordered the August issue of The Masses to be excluded from the mail, exercising his authority under the Espionage Act of 1917. The Masses sought an injunction to forbid the local postmaster from refusing to accept the August issue for mailing. ${ }^{29}$ The postmaster argued that four cartoons and four pieces of text violated the Act, thus justifying the order of exclusion.

Illustrative of these was a cartoon by Henry J. Glentenkamp entitled "Conscription" and a poem by Josephine Bell entitled "A Tribute." The cartoon depicted a cannon, to the mouth of which is bound the naked figure of a youth, to the wheel that of a woman marked "Democracy," and upon the carriage that of a man marked "Labor." On the ground kneels a draped woman marked "Motherhood" in a posture of grief. An infant lies on the ground beside her."

The poem, a "tribute" to Emma Goldman and Alexander Berkman, who were then in jail for opposing the war and the draft, included the following verse:

Emma Goldman and Alexander Berkman

Are in prison tonight,

But they have made themselves elemental forces,

Like the water that climbs down the rocks;

Like the wind in the leaves;

Like the gentle night that holds us;

They are working on our destinies;

They are forging the love of the nations; ...

Tonight they lie in prison.

The postmaster argued that the cartoons and text violated section 3 of the Espionage Act, in that they willfully caused or attempted "to cause insubordination, disloyalty, mutiny or refusal of duty in the military or naval forces" and obstructed "the recruiting or enlistment service of the United States." ${ }^{33}$ Judge Learned Hand granted the injunction and prohibited the postmaster from excluding The Masses from the mail.

Judge Hand fully appreciated the significance of this case for him personally. Hand knew he was then under consideration for promotion to the court of appeals, a promotion he richly deserved and much desired. When he learned that he had been assigned the case, he wrote

29 Murphy, World War I and the Origin of Civil Liberties at 196 (cited in note 7).

30 See Masses, $244 \mathrm{~F}$ at 542-43.

31 The cartoon is reprinted in Rabban, Free Speech in Its Forgotten Years at 263 (cited in note 3 ).

32 The verse is reprinted in Masses, $244 \mathrm{~F}$ at 544.

33 Id at 536-37. 
his wife that if the case were not quickly settled, "my decision would go against [the government], and then whoop-la your little man is in the mud." He added that "[t] here are times when the old bunk about an independent and fearless judiciary means a good deal."

Judge Hand began his opinion by observing that in times of war "[i]t may be that Congress may forbid the mails to any matter which tends to discourage the successful prosecution of the war." ${ }^{, 35}$ But he did not need to resolve the First Amendment issue because, in his judgment, the Act did not cover the material published in The Masses.

Judge Hand conceded the postmaster's claim that "to arouse discontent and disaffection among the people with the prosecution of the war and with the draft tends to promote a mutinous and insubordinate temper among the troops." But he argued that to read to word "cause" so "broadly would ... involve necessarily as a consequence the suppression of all hostile criticism, and of all opinion except what encouraged and supported the existing policies." ${ }^{36}$

34 Gunther, Learned Hand at 155 (cited in note 26). Judge Hand was not the only federal district court judge to adopt a speech-protective interpretation of the Espionage Act of 1917. Judge George Bourquin of Montana presided over the prosecution of Ves Hall, who was alleged to have announced in a series of encounters at a picnic, in a hotel kitchen, and in a saloon that "he would flee to avoid going to war," that "Germany would whip the United States, and he hoped so," that "the President was a Wall Street tool," that Germany had had the right "to sink ships and kill Americans without warning," and that "the United States was only fighting for Wall Street millionaires and to protect Morgan's interests in England." United States $v$ Hall, (unreported) (D Mont 1918), printed in HR 8753, 65th Cong, 2d Sess, in 56 Cong Rec S 4560 (Apr 4, 1918).

Hall was charged with violating Section 3 of the Act. Judge Bourquin directed a verdict of acquittal, finding that Hall's comments could not be held to violate Section 3 . Judge Bourquin noted that Hall's comments "were made at a Montana village of some sixty people, sixty miles from the railway," and that no soldiers or sailors were "within hundreds of miles." He therefore concluded that any inference that Hall's remarks had been specifically intended to "interfere with the operations or success of the military," or were reasonably likely to do so, would be "unjustified, absurd and without support in the evidence." Judge Bourquin offered that in these circumstances the most likely consequence of Hall's speech was "a broken head." Id. Senator Walsh described Judge Bourquin's decision in Hall as "notorious" and predicted that it would unleash "those who might be disposed to assist the cause of our enemies." HR 8753, 65th Cong, 2d Sess, in 56 Cong Rec S 4559-60 (Apr 4, 1918). The day after Judge Bourquin's ruling, the Governor of Montana announced that the citizens of the state were so furious that "I really expect some killing." Murphy, World War I and the Origin of Civil Liberties at 200 (cited in note 7).

Another federal district court judge who construed the Espionage Act "narrowly" was Judge Charles Fremont Amidon of North Dakota. In United States v Schutte, 252 F 212, 214 (D ND 1918), for example, Judge Amidon dismissed the prosecution of B.H. Schutte, a farmer who had stated publicly that "this is a rich man's war and it is all a damn graft and a swindle." Judge Amidon explained that there was no evidence that Schutte's comments had been made to an audience containing men who were in the armed forces or who were eligible for the draft. See id. Judge Amidon was pilloried in the North Dakota press, denounced by the president of the North Dakota Bar Association, ostracized by friends and associates, and threatened in letters and phone calls. See Murphy, World War I and the Origin of Civil Liberties at 208-09 (cited in note 7).

35 Masses, $244 \mathrm{~F}$ at 538.

36 Id at 539 . 
Judge Hand reasoned that such an approach "would contradict the normal assumption of democratic government," and even assuming that Congress would have the power in time of war "to repress such opinion," the exercise of that power "is so contrary to the use and wont of our people that only the clearest expression of such a power justifies the conclusion that it was intended." In these circumstances, he concluded, the actual "language of the statute" did not require such an interpretation.

This was a critical step in Judge's Hand opinion, and it is the step I address in this Essay. As I noted at the outset, the conventional wisdom is that this was merely a rhetorical device-and a shady one at that - to enable Judge Hand to reach his desired outcome. ${ }^{38}$ This is wrong.

There were two elements to Judge Hand's reasoning. First, as of 1917, was it reasonable for Judge Hand to conclude that a broad prohibition of all criticism that "could arouse discontent and disaffection among the people" during a war is "contrary to the use and wont of our people"? The answer, as of that time in our history, has to be "yes."

The clearest example to the contrary was the Sedition Act of 1798 , but by 1917 no one invoked that episode as a positive example. To the contrary, it was consistently referred to in the debates over the Espionage Act as a mistake to be avoided. ${ }^{39}$ In the years since 1800 , there had never been any federal legislation restricting this sort of speech in wartime (or otherwise), including the War of 1812, the Civil War, the Mexican War, and the Spanish-American War. And although the military arrest and prosecution of Clement Vallandigham and several other "Copperheads" during the Civil War would fit generally within this description (albeit without any authorizing federal legislation), they were relatively isolated events that were regarded more as

37 Id at 540. There are, of course, many complex and controversial theories of statutory interpretation. Because my inquiry in this Essay is relatively modest, it does not implicate the many intricacies of these competing theories. In the end, my point is simply that there is no reason to believe that a majority of those in Congress who supported the Espionage Act intended or expected it to depart radically from generally accepted principles of criminal law or to have the far-reaching effects the courts attributed to it within a very short period of time. On the various theories of statutory interpretation, see William Eskridge, Philip Frickey, and Elizabeth Garrett, Cases and Materials on Legislation 669-71 (West 2001).

38 See, for example, Rabban, Free Speech in Its Forgotten Years at 265 (cited in note 3) (stating that Hand's "confident assertion" that Congress did not intend to "invoke such power" with the Espionage Act was belied by the Act's legislative history).

39 See Michael Kent Curtis, Free Speech, "The People's Darling Privilege": Struggles for Freedom of Expression in American History 317-18 (Duke 2000) (stating that though Civil Warera supporters of suppression of speech might have cited the Sedition Act, their failure to do so "shows the extent to which the robust popular free speech tradition had triumphed on that issue").

40 See id at 5 (stating that from 1800 to 1860 " [t] he national government had little or no power over speech or press"). 
an embarrassment to Lincoln and the nation than as a precedent to be followed. ${ }^{41}$

Second, was it reasonable for Judge Hand to conclude that the Espionage Act of 1917 did not require the interpretation advocated by the Postmaster General and embraced by almost every other federal court? To answer this question, we must consider the legislative history of the Espionage Act.

\section{THE LEgISLATIVE History OF THE ESPIONAGE ACT OF 1917}

Three sections of the bill initially drafted by the Department of Justice are relevant to this question. For the sake of convenience, I will refer to them as the "press censorship" provision, the "disaffection" provision, and the "nonmailability" provision. An understanding of the debate over these provisions is essential to understanding the legislative background against which Judge Hand interpreted the Espionage Act in Masses.

As presented to Congress, the "press censorship" provision would have declared it unlawful for any person in time of war to publish any information that the President, in his judgment, declared to be "of such character that it is or might be useful to the enemy." The provision added that "nothing in this section shall be construed to limit or restrict any discussion, comment, or criticism of the acts or policies of the Government.",

The "disaffection" provision would have declared it unlawful for any person in time of war: (a) willfully to "make or convey false reports or false statements with intent to interfere with the operation or success" of the military forces of the United States or "to promote the success of its enemies," or (b) willfully to "cause or attempt to cause disaffection in the military or naval forces of the United States.",

41 See id at 348-56 (examining the effects of Vallandigham's arrest for open opposition to the Civil War and the Lincoln Administration and noting that the "high public regard for freedom of speech" and "strong negative reaction to the Vallandigham case" led Lincoln to limit his policy of speech suppression); Paul Finkelman, Civil Liberties and Civil War: The Great Emancipator as Civil Libertarian, 91 Mich L Rev 1353, 1380 (1993) ("The arrests and violations of civil liberties under Lincoln illustrate the propensity for prosecutorial zeal during wartime."); Mark E. Neely, Jr., The Fate of Liberty: Abraham Lincoln and Civil Liberties 205 (Oxford 1991) ("No single arrest in 1864 dramatized or symbolized the civil-liberties issue, as Vallandigham's had in 1863."); J.G. Randall, Constitutional Problems under Lincoln 179 n 16 (Illinois rev ed 1951) (quoting Lincoln as saying that "[a]ll the Cabinet regretted the necessity of arresting ... Vallandigham" and noting that the President commuted Vallandigham's sentence from confinement to expulsion to the Confederacy).

42 HR 291 tit I \& 4, 65th Cong, 1st Sess, in 55 Cong Rec H 1695 (May 2, 1917).

43 See 54 Cong Rec S 3606-07 (Feb 19, 1917) (discussing the use of the word "disaffection"). Violations were punishable by fines of up to $\$ 10,000$ and prison sentences of up to twenty years, or both. See Espionage Act of 1917,40 Stat at 219. 
The "nonmailability" provision would have granted the Postmaster General authority to exclude from the mails any writing or publication that is "in violation of any of the provisions of this act" or is "of a treasonable or anarchistic character."

The "press censorship" provision provoked the most heated discussion. Indeed, the Wilson administration's proposal of this provision triggered a firestorm of protest from the press, which objected that the provision would effectively give the President the final authority to determine whether the press could, or could not, publish information about the conduct of the war. The American Newspaper Publishers' Association, for example, declared that this provision "strikes at the fundamental rights of the people, not only assailing their freedom of speech but also seeking to deprive them of the means of forming intelligent opinion." The Association added that "in war especially the press should be free, vigilant, and unfettered." ${ }^{45}$

Individual newspapers were equally critical. The New York Times assailed the provision as "high-handed" and "Prussian," asserting that "the newspaper or the individual who criticizes or points out defect in policies ... with the honest purpose of promoting remedial action ... is not a public enemy." ${ }^{, 46}$ The Milwaukee News characterized the press censorship provision as a "glaring attempt ... to muzzle the press" that "smack[s] of unconstitutionality, tyranny, and deceit." And the Philadelphia Evening Telegraph stated that "it is neither necessary nor reasonable that there should be any power in this country ... to control the voice of the press, or of the people, in honest judgment of the acts of public servants."

When the "press censorship" provision was first presented to the House on April 30,1917, Representative Webb of North Carolina, the Chairman of the House Judiciary Committee, initiated the debate by announcing that the nation's newspapers had unfairly "created the impression" that the Committee, which had approved the bill, "was undertaking to unduly abridge the freedom of the press." He sternly reminded the press that:

44 Report of the Committee on the Judiciary of the House of Representatives, Report No 30, 65th Cong, 1st Sess 9 (1917); HR $291 \S 1100,65$ th Cong, 1st Sess, in 55 Cong Rec H 1595 (Apr 30, 1917); Letter from W.W. Lamar, Solicitor of the Post Office Department, to Rep Edwin Y. Webb, 65th Cong, 1st Sess (Apr 20, 1917), in 55 Cong Rec H 1595 (Apr 30, 1917).

45 Resolutions of the American Newspaper Publishers' Association, 65th Cong, 1st Sess (Apr 25, 1917), in 55 Cong Rec S 1861 (May 5, 1917).

46 The Espionage Bill, NY Times 12 (Apr 13, 1917).

47 Milwaukee News (Apr 30,1917), quoted in Thomas F. Carroll, Freedom of Speech and of the Press in War Time: The Espionage Act, 17 Mich L Rev 621, 624 (1919).

48 Quoted in Oppose Censorship as Now Proposed, NY Times 7 (Apr 22, 1917). See also 65th Cong, 1st Sess, in 55 Cong Rec H 1709-10 (May 2, 1917) (similar editorials from the New York American, the Philadelphia Inquirer, and the Washington Times). 
[I]n time of war, while men are giving up their sons and while people are giving up their money, [the press] should at least be willing to give up their right ... to publish ... those things which the President of the United States thinks would be hurtful to the United States and helpful to the enemy. ${ }^{49}$

Representative Webb argued further:

We are in just one of those situations where we have to trust somebody. The President is the Commander in Chief ... and he has in his hands the military control of the boys of the mothers of the country, and ... that is as sacred a trust as it is for him to prescribe what in his opinion is information which would be useful to the enemy.

Echoing this view, Senator Husting of Wisconsin maintained that these "are extraordinary measures, and I would not support them as peace measures, but we are now in extraordinary times ... [and] extraordinary remedies are necessary if we want to maintain the integrity and the safety of this Nation."

Senator Overman of North Carolina argued that "the good of society is superior to the right of the press to publish what it pleases; wherefore, if the activities of newspapers were a hindrance in the prosecution of the war, their curtailment would not be unconstitutional." ${ }^{52}$ Representative Volstead of Minnesota asked pointedly how the nation would feel if American troops were "sent to the bottom of the sea as a result of information" published because this provision is not enacted. "It is utterly ridiculous," he declared, "for anybody to contend that this provision is unconstitutional."

The opposition to the provision was fierce. Representative Fess of Ohio warned that "in time of war we are very apt to do things that we would not think of doing in time of peace," and that this is a "danger when we are in a spirit of war." "Senator Johnson of California reminded his colleagues that "the preservation of free speech" is of "transcendent importance ... whenever there is a time of stress,

49 65th Cong, 1st Sess, in 55 Cong Rec H 1590-91 (Apr 30, 1917). See also id at 1695 (May 2,1917 ) (Rep Morgan's observation that "in time of great national peril, it is necessary sometimes that individual citizens shall be willing to surrender some of the privileges which they have for the sake of the greater good").

50 65th Cong, 1st Sess, in 55 Cong Rec H 1592 (Apr 30, 1917). See also Carroll, 17 Mich L Rev at 627 (cited in note 47) (noting that an important defense of the provision was the argument that "the President, as Commander-in-Chief of the military forces, is the best judge" of whether such control of the press is "necessary to carry the war to a successful conclusion").

51 65th Cong, 1st Sess, in 55 Cong Rec S 2087 (May 11, 1917).

52 Carroll, 17 Mich L Rev at 628 (cited in note 47).

53 65th Cong, 1st Sess, in 55 Cong Rec H 3137 (May 31, 1917).

54 65th Cong, 1st Sess, in 55 Cong Rec H 1591 (Apr 30, 1917). 
whenever there is excitement, whenever there are enthusiasms in which we lose our judgment.", 55

Describing the provision as "un-American," Representative Madden of Illinois protested that "while we are fighting to establish the democracy of the world, we ought not to do the thing that will establish autocracy in America., ${ }^{, 56}$ Senator Borah of Idaho charged that the provision "boldly, brazenly, indifferently [disregards] a plain, vital provision of our fundamental law." ${ }^{, 7}$ Senator Henry Cabot Lodge expressed concern that the government officials who would administer this provision would naturally be inclined to use their authority to censor legitimate public criticism. ${ }^{58}$ And Representative McCormick of Illinois, voicing a concern expressed by many members of Congress, and using a variety of different hypothetical situations, noted that it was appalling to think that if "there was an epidemic in the Army" the proposed provision would authorize the President to prohibit anyone from "drawing public attention to the condition of the troops.",

Proponents of the provision repeatedly invoked the clause guaranteeing that "nothing in this section shall be construed to limit or restrict any discussion, comment, or criticism of the acts or policies of the Government.", ${ }^{, 60}$ Opponents replied that it was impossible effectively to criticize the "policies of the Government" without discussing the information on which the criticism was based. Representative Volstead tried to reassure opponents of the provision by stating that he

55 65th Cong, 1st Sess, in 55 Cong Rec S 2097 (May 11, 1917). Rep LaGuardia of New York characterized the provision as a potentially "vicious precedent," 65 th Cong, 1st Sess, in 55 Cong Rec H 1594 (Apr 30,1917), and Rep Wood of Indiana warned that it would be "an instrument of tyranny," 65th Cong, 1st Sess, in 55 Cong Rec H 1773 (May 3, 1917). Rep Schall of Minnesota proclaimed that "America is not made of the stuff that has to be coddled along with tales of winning to make her fight." All that is needed, he said, is to "[t]ell her the truth." 65 th Cong, $1 \mathrm{st}$ Sess, in 55 Cong Rec H 1775 (May 3, 1917).

56 65th Cong, 1st Sess, in 55 Cong Rec H 1773 (May 3, 1917).

57 65th Cong, 1st Sess, in 55 Cong Rec S 2119 (May 11, 1917). On another occasion, Senator Borah said that the Act "has all the ear marks of a dictatorship. It suppresses free speech and does it all in the name of war and patriotism." Claudius O. Johnson, Borah of Idaho 214 (Longmans, Green 1936) (quoting a letter from Sen Borah to a friend). See also Paul L. Murphy, Communities in Conflict, in Alan Reitman, ed, The Pulse of Freedom: American Liberties 19201970s 23, 25 (Norton 1975) (quoting Sen Borah: "I am charged with radicalism for opposing government repression.").

58 65th Cong, 1st Sess, in 55 Cong Rec S 781 (Apr 18, 1917) (stating that the Act would vest the censorship board with "a dangerous power").

59 65th Cong, 1st Sess, in 55 Cong Rec H 1606 (Apr 30, 1917). For another example, see 65 th Cong, 1st Sess, in 55 Cong Rec S 2099 (May 11, 1917) (under this provision "it would be a violation of law for the newspapers of the country ... to print the crop reports, which are intimately related to our military efficiency and the national defense") (remarks of Sen Smith). For a counterexample, see 65th Cong, 1st Sess, in 55 Cong Rec S 2102 (May 11, 1917) (it would be "the height of unwisdom to make public in the midst of war ... the intention of this Government ... to cover the North Sea with submerged floating mines") (remarks of Sen Stone).

60 See 65th Cong, 1st Sess, in 55 Cong Rec H 1602 (Apr 30, 1917) (quoting Rep Platt reading the relevant section to the House). 
had "no doubt that when a man" speaks "with good intentions ... there will be no difficulty at all."

At times, the debate grew quite testy. At one point, Representative Webb accused Representative Madden, who was questioning the constitutionality of the provision, of "taking the part of the newspapers." Madden replied: "I am taking the part of the American people."

When it began to appear that the press censorship proposal might go down to defeat, President Wilson made a direct appeal to Congress, stating that the "authority to exercise censorship over the press ... is absolutely necessary to the public safety." ${ }^{63}$ Members of Congress were unmoved. Representative Hersey of Maine, for example, complained that "we, the Congress of the United States," are now "importuned by the executive ... to enact unconstitutional laws, to place in the hands of the President unlawful powers, to grant to him the ... authority to take away from the citizen the protection of the Constitution."

On May 31, the House defeated the provision by a vote of 184 to 144, with 36 Democrats joining the Republican opposition. ${ }^{65}$ This effectively ended consideration of the "press censorship" provision for the duration of the war. ${ }^{66}$

The "nonmailability" provision also generated controversy. Several members of Congress objected to granting the Postmaster General such broad authority to exclude political material from the mails. Senator Thomas of Colorado, for example, argued that this provision would enable postmasters to exclude "legitimate" as well as illegitimate publications, and would thus produce "a far greater evil than the evil which is sought to be prevented." Representative London of New York declared the provision a "menace to freedom," adding that "there is nothing more oppressive ... than a democracy gone mad."

61 65th Cong, 1st Sess, in 55 Cong Rec H 1607 (Apr 30, 1917).

62 65th Cong, 1st Sess, in 55 Cong Rec H 1593 (Apr 30, 1917).

63 Wilson Demands Press Censorship, NY Times 1 (May 23, 1917) (quoting a letter from Woodrow Wilson to Rep Webb). The administration offered a "compromise" version of the press censorship provision, which failed to pass. See Conf Rep No 65, on HR 291, 65th Cong, 1st Sess, in 55 Cong Rec $H$ 3124, 3125 (May 31, 1917) (amended press censorship provision in title I, section 4).

64 65th Cong, 1st Sess, in 55 Cong Rec H 3134 (May 31, 1917).

65 See House Defeats Censorship Law by 184 to 144, NY Times 1 (June 1, 1917) (stating that party lines were "shattered" in defeating the bill).

66 The House instructed the conferees to strike the press censorship provision from the bill. See House of Representatives Report No 69, 65th Cong, 1st Sess 19 (1917). The press censorship provision appeared at title I, section 4 of the bill. See Report of the Committee on the Judiciary, No 30 at 2 (cited in note 44 ).

67 65th Cong, 1st Sess, in 55 Cong Rec S 2062 (May 10, 1917).

68 65th Cong, 1st Sess, in 55 Cong Rec H 1779 (May 3, 1917) (noting that while the press censorship provision was a menace to newspapers, the "nonmailability" provision was a "menace to all"). 
And Senator Borah cautioned that "it is perfectly useless to talk about stopping the dissemination and interchange of thought and views upon these questions among the people of the United States" because "the more you dam up the stream the more liable you are to have a flood when it breaks over."

There was particular concern about the phrases "treasonable" and "anarchistic." This led to a lengthy and rather remarkable debate over the meaning, or lack of meaning, of these terms. ${ }^{70}$ Representative Johnson objected that this provision would be "subject to the ruling of whomever happens to be high in the Post Office Department." As if to illustrate the point, Representative Eagle, quoting a letter from the Socialist Party, made clear his view that "they have a perfect right to say" that the Party "strongly affirms its allegiance to the principle of internationalism," but that it is "treasonable" for the Party to say that the war against Germany "cannot be justified."

After vigorous debate, Congress amended the "nonmailability" provision to replace the phrase "treasonable or anarchistic character" with the much narrower phrase "containing any matter advocating or urging treason, insurrection or forcible resistance to any law of the United States." ${ }^{, 73}$ Thus, Congress took seriously the constitutional and policy objections to granting too broad a discretion to the Postmaster General and significantly limited and sharpened the scope of his authority.

69 65th Cong, 1st Sess, in 55 Cong Rec S 2062 (May 10, 1917) (noting that similar attempts during the Civil War "wrought a greater evil than would [otherwise] have resulted"). See also 65th Cong, 1st Sess, in 55 Cong Rec S 2118-19 (May 11, 1917) (Sen Borah: "There is not a single decision to be cited anywhere but holds that any law which undertakes to control the publication previous to its publication is in violation of the Constitution.").

70 65th Cong, 1st Sess, in 55 Cong Rec H 1595-97 (Apr 30, 1917) (beginning with the question from Rep Fess, "Treasonable' is defined, but what is 'anarchistic'?"). The debate also touched upon "nihilism" and the views of Tolstoy and Emerson.

71 65th Cong, 1st Sess, in 55 Cong Rec H 1604 (Apr 30, 1917) (noting that the opinion of the solicitor of the Post Office Department would "prevail without a trial").

72 65th Cong, 1st Sess, in 55 Cong Rec H 1607 (Apr 30, 1917).

73 Conf Rep No 65, on HR 291, 65th Cong, 1st Sess, in 55 Cong Rec H 3124, 3129 (May 29, 1917); 65th Cong, 1st Sess, in 55 Cong Rec H 3306 (June 7, 1917).

74 One might ask why Congress refused to give the President any discretion over the press in the "press censorship" provision but was willing to give some discretion to the Postmaster General in the "nonmailability" provision. One possible explanation is that the press itself was much more concerned with the "press censorship" provision because it would apply even to mainstream newspapers. See Rabban, Free Speech in Its Forgotten Years at 253 (cited in note 3) (noting the contradiction between Congress's treatment of the press censorship provision and its treatment of the "nonmailability" provision). Another possible explanation is that the Postmaster General had always had some authority to exclude materials from the mails (for example, obscene material), whereas the President had never been empowered by Congress to exercise such authority over the press. 
The "disaffection" provision, which turned out to be the most important provision of the bill, received less attention. ${ }^{75}$ But even this provision was amended in a very significant manner.

The difficulties with the "disaffection" provision were made most clear in the hearings before the House Committee on the Judiciary. Gilbert Roe, a distinguished attorney who represented the Free Speech League, testified that this provision was even more troublesome than the Sedition Act of 1798. Roe explained that the Sedition Act granted the defense of truth. Under the "disaffection" provision, however, every effort to discuss or criticize the conduct of the war is "brought under the ban of the proposed statute." Indeed, under the "disaffection" provision, "the matter published or spoken may be the truth, and probably the greater the truth the greater the disaffection its dissemination would cause." To illustrate the magnitude of the problem, Roe noted that "the people ... retain their right at the next election to return to Congress Senators and Representatives ... who are opposed to the continuation of the war." How, he asked the Committee, is any voter "to form an intelligent opinion" on this question "unless there is the fullest discussion permitted of every phase of the war, its origin, its manner of prosecution, and its manner of termination?"76

Professor Emily Balch of Wellesley College also testified against the "disaffection" provision. Balch noted because this provision will be enforced in wartime it was essential to guard against the risks of war hysteria. Representative Caraway assured Balch that "it is the intent to cause disaffection" and not the intent "to right a wrong" that makes a statement criminal. Professor Balch was not comforted. She replied that if an individual criticized the conduct of the war in order "to right a wrong," the prosecutor could nonetheless argue that the statement had contributed to disaffection and that the defendant should have expected that result. Balch was concerned that the prosecutor could then try to equate expectation with intent. When reminded by Representative Whaley that this was not entirely up to the prosecution because a jury would have to rule on intent, Professor Balch responded that "in time of war a jury ... is no less liable to hysteria than those higher up."

In light of such concerns, the Committee found the phrase "disaffection" to be "too broad," "too elastic," and "too indefinite." In or-

75 See id at 250 ("It is ironic that the section of the bill that ultimately provided the basis for most of the prosecution hardly received any attention [from Congress].").

76 Hearings before the House of Representatives Committee on the Judiciary, 65th Cong, 1st Sess, Hearings on HR 291 at 36-43 (Apr 9 \& 12, 1917).

77 Id at 12-13.

78 65th Cong, 1st Sess, in 55 Cong Rec H 1594 (Apr 30, 1917) (Rep Webb). 
der to narrow and clarify this provision, the Committee replaced the phrase "cause or attempt to cause disaffection" with the phrase "cause or attempt to cause insubordination, disloyalty, mutiny, or refusal of duty." Representative Webb explained that "to make it a crime to create disaffection" in the military "might subject a perfectly innocent person to punishment," offering as an illustration the case of a mother who "might write to a boy and tell him the sad conditions back home.",

After nine weeks of sometimes grueling, sometimes divisive, and sometimes impassioned debate, Congress enacted the Espionage Act of 1917. After the various emendations, including the elimination of the "press censorship" provision and the narrowing amendments to the "disaffection" and "nonmailability" provisions, the relevant part of section 3 of title $I$ of the Act made it a crime when the nation is at war for any person: (a) willfully to "make or convey false reports or false statements with intent to interfere" with the military success of the United States or "to promote the success of its enemies"; (b) willfully to "cause or attempt to cause insubordination, disloyalty, mutiny, or refusal of duty, in the military or naval forces of the United States"; or (c) willfully to "obstruct the recruiting or enlistment service of the United States." ${ }^{\text {"81 }}$ The Act also authorized the Postmaster General to exclude from the mails any writing or publication that is "in violation of any of the provisions of this act" or that contains "any matter advocating or urging treason, insurrection or forcible resistance to any law of the United States."

As the congressional debate suggests, the legislation, as enacted, was not a broadside attack on all criticism of the war. It was, rather, a carefully considered enactment designed to deal with very specific military concerns. Although Congress's stance in enacting the Espionage Act could hardly be characterized as civil libertarian, its elimination of the press censorship provision (over the strong objections of the President) and its significant amendments to both the "disaffection" and "nonmailability" provisions reflected a genuine concern for the potential impact of the legislation on the freedom of speech and of the press. As Special Assistant Attorney General John Lord O'Brian observed in 1919, the Espionage Act of 1917 "was not directed against disloyal utterances." Rather, its "sole aim was to protect the process of

79 See Espionage Act of 1917,40 Stat at 219.

80 65th Cong, 1st Sess, in 55 Cong Rec H 1594-95 (Apr 30, 1917).

81 Espionage Act of 1917, 40 Stat at 219. What I have labeled provision (c) was not in the original bill, but was added during the course of congressional deliberations.

82 Espionage Act of 1917, 40 Stat at 230-31. 
raising and maintaining our armed forces from the dangers of disloyal propaganda." ${ }^{23}$

Indeed, throughout the debate on the Act, there were expansive statements about the importance of free speech, even in wartime. Representative Cooper of Wisconsin, for example, maintained that "in this Republic mere "error of opinion is never dangerous when reason is free to combat it." ${ }^{84}$ Representative London of New York declared that "[i]f there are any treasonable thoughts in the minds of the American people, I want them expressed; if there is any discontent with the war, I want to hear it." He conceded that complaints about the conduct of the war or about "a shortage of food" or "incompetence in high places" will be "encouraging to the enemy." But, he asked, "[s]hall we suppress them, or shall we find compensation in the opportunity to have wrongs righted by the curing power of free discussion?" colleagues that "there is in this bill no prohibition on criticism, or censure, or even ridicule of any of the acts or operations or policies of the Government, or any of its representatives." ${ }^{, 86}$ And even Representative Webb, the Chairman of the House Committee on the Judiciary, emphasized that under the Act "[i]t is no crime to call the flag a dirty rag."

Although there were as many statements expressing a more restrictive view of the First Amendment, the overall sense of the congressional debate suggests a lack of any clear consensus about either the likely effects of the Act or the meaning of the freedom of speech. As Senator Borah noted with exasperation at one point in the debate, "I have not found any two Senators who agree upon what [the Act] means.",88

This lack of common understanding was strikingly evident in the hearings before the House Committee on the Judiciary. Mrs. William Thomas, who represented the Women's Peace Party, asked the Committee whether under the Act "I am to be allowed ... to say I do not

83 O'Brian, 42 Rep NY St Bar Assn at 299-300 (cited in note 4).

84 65th Cong, 1st Sess, in 55 Cong Rec H 1597 (Apr 30, 1917) (Rep Cooper quoting Thomas Jefferson).

85 65th Cong, 1st Sess, in 55 Cong Rec H 1780 (May 3, 1917) (Rep London stating that he would support "every measure that will guard the military and naval secrets of the country," but nothing more).

86 65th Cong, 1st Sess, in 55 Cong Rec S 2116 (May 11, 1917). On the other hand, in the same speech, Senator Sterling also quoted approvingly an excerpt from a publication stating that if a newspaper "publishes statements the obvious effect and probable purpose of which are to give aid and comfort to the enemy, its editor should be liable to punishment." Id.

87 65th Cong, 1st Sess, in 55 Cong Rec H 1596 (Apr 30, 1917).

88 65th Cong, 1st Sess, in 55 Cong Rec S 2120 (May 11, 1917). Although Senator Borah was referring specifically to the press censorship provision, his observation was clearly applicable more generally. 
believe in killing human beings and I do not want my sons to ... kill other women's sons?" She received a range of confused and confusing responses.

Chairman Webb, for example, replied that "you may voice a conscientious objection to fighting, but you can not go on with this propaganda, if it is calculated to interfere with the military forces." Representative Walker added that "now that we are at war ... you ought not do anything which would prevent us from bringing the war to a successful conclusion." Representative Summers opined that if "somebody was trying to enlist men on one corner of a street . . . and you were having a meeting on the other corner in which you were denouncing the Government,... I do not believe you could have such a meeting." And Representative Dyer, venting his evident annoyance with Mrs. Thomas, declared that "this bill would not permit you to hold meetings and have speeches criticizing the President." To underscore the point, he added that "people should go ahead and obey the law, keep their mouths shut, and let the Government run the war." Representative Eaton, attempting to exert a calming influence, suggested that there appears to be "a distinct vagueness among the members of the committee as to how far this abridgment of speech is going." ${ }^{89}$

One thing that was certain, however, was the administration's disappointment in the legislation as enacted. Attorney General Gregory expressed his frustration a year later in a statement to the American Bar Association, whose support he was then seeking for an expanded version of section three. The Attorney General complained that when the war "broke out" the administration "secured the passage of the Espionage Act, but most of the teeth which we tried to put in it were taken out." "We got what we could," he added, "but Congress itself did not realize at that time the conditions that would confront us." The changes Congress had made to section three were clearly of consequence to the Department of Justice, which had sought and expected a more effective tool to control dissent.

\section{JUDGE HAND'S UNDERSTANDING OF THE ESPIONAGE ACT OF 1917}

This brings me back to the question of whether Congress intended the Espionage Act to have the effect given it by the federal judiciary. The answer is clearly "no." In light of Congress's elimination of

89 Hearings before the House of Representatives Committee on the Judiciary, 65th Cong, 1st Sess, Hearings on HR 291 at 19-25 (Apr 9 \& 12,1917).

90 Thomas Gregory, Suggestions of Attorney General Gregory to Executive Committee in Relation to the Department of Justice, 4 ABA J 305, 306 (1918). 
the press censorship provision, its rejection of the "disaffection" provision, and its abandonment of the "treasonable or anarchistic" language in the "nonmailability" provision, it seems unarguable that Congress did not intend this Act to outlaw any criticism of the government or the war that "could arouse discontent and disaffection among the people." Had Congress wanted to prohibit expression so broadly, it could surely have said so."

What Congress did say in the Espionage Act of 1917 was that it wanted to restrict expression only if it willfully caused or attempted to cause certain specifically defined consequences concerning the effectiveness of the armed forces of the nation. Although the precise line between speech that falls within that prohibition and speech that falls beyond it is far from clear, and not always easy to define or enforce, there can be no doubt that in 1917 Congress meant for there to be some such line.

The challenge for Judge Hand, then, was to separate "legitimate" from "illegitimate" speech under the Act." Judge Hand began his analysis of this question by asserting that it "has always" been recognized that "[o]ne may not counsel or advise others to violate the law as it stands." Words, he observed, "are not only the keys of persuasion, but the triggers of action, and those which have no purport but to counsel the violation of law cannot by any latitude of interpretation be a part of that public opinion which is the final source of government in a democratic state.",93

Judge Hand conceded that speech falling short of express incitement to violate the law can have negative consequences. "Political agitation," he noted, "by the passions it arouses or the convictions in engenders, may ... stimulate men to the violation of law," and "[d]etestation of existing policies is easily transformed into forcible resistance of the authority which puts them in execution." But, he reasoned, "to assimilate agitation, legitimate as such, with direct incitement to violent resistance, is to disregard the tolerance of all methods of political agitation which in normal times is a safeguard of free government." This "distinction," he emphasized, "is not a scholastic subterfuge, but a hard-bought acquisition in the fight for freedom."

91 Indeed, Congress did say so a year later in the Sedition Act of 1918, in which it declared it unlawful, among other things, for any person to "utter, print, write or publish any disloyal, profane, scurrilous, or abusive language about the form of government of the United States, or the Constitution of the United States, or the military or naval forces of the United States, or the flag." Sedition Act of 1918, 40 Stat 553.

92 Although Judge Hand did not cite any of the legislative history of the 1917 Act in Masses, he was surely familiar with the debate in Congress, which was widely covered in the press.

Masses, $244 \mathrm{~F}$ at 540.

94 Id. 
Judge Hand thus concluded that "[i]f one stops short of urging" others to violate the law, "one should not be held to have attempted to cause its violation. If that be not the test," he cautioned, "I can see no escape from the conclusion that under this [Act] every political agitation which can be shown to be apt to create a seditious temper is illegal." He declared his confidence that "Congress had no such revolutionary purpose in view." Applying this approach to the facts of Masses, Judge Hand held that neither the cartoons nor the text crossed the line of direct advocacy of unlawful conduct. ${ }^{*}$

\section{CONCLUSION}

Most federal judges during the First World War were "intent upon meting out quick justice and severe punishment to the 'disloyal," and no details of legislative interpretation or appeals to the First Amendment were likely "to stand in the way." As Special Assistant Attorney General O'Brian concluded, "The standard by which

95 Id. One might ask whether the 1918 Sedition Act, which was enacted well after Judge Hand's decision in Masses, was designed to enact unambiguously what Congress had actually intended to enact in the 1917 Espionage Act. On that view, the terms of the 1918 Act might be read back into the 1917 Act, and Judge Hand's understanding of the Espionage Act would then surely be wrong. But this is implausible. The purpose of the 1918 Act was quite clearly to broaden and strengthen the prohibitions of the Espionage Act. A year of war, with all of its casualties, had significantly changed the mood of the country and the Congress. Whatever tolerance may have existed for dissent in 1917 was largely dissipated after a year of brutal conflict and unrelenting government-sponsored anti-German propaganda. See also Chafee, Free Speech in the United States at 40 (cited in note 19) (the enactment of the Sedition Act shows "what is likely to happen in times of panic"). Throughout the debates on the Sedition Act, almost every member of Congress found it necessary to proclaim his loyalty to the nation and to the cause. The atmosphere carried a strong undercurrent of repression. At one point, Senator Henry Cabot Lodge complained that "I have become a little weary of having Sens get up here and say to those of us who happen to think a word had better be changed" that "we are trying to shelter treason." Cong Rec, 65th Cong, 2d Sess, in 56 Cong Rec S 4783 (Apr 8, 1918). Similarly, after declaring his opposition to the 1918 Act, Senator Johnson of California observed that "what has transpired again and again" both "in this Chamber" and "all over this land" is that "any man who did not subscribe instanter to any doctrine, however subversive of this Republic and of its fundamental principles," has by "that very token" been charged with "disloyalty." Cong Rec, 65th Cong, 2d Sess, in 56 Cong Rec S 4566 (Apr 4, 1918). On the government war propaganda, see Murphy, World War I and the Origin of Civil Liberties in the United States at 107-12 (cited in note 7) (detailing government efforts to vilify Germany and to convince the public that civil rights restrictions were permissible during hostilities); Meirion Harries and Susan Harries, The Last Days of Innocence: America at War 1917-1918 282-308 (Random House 1997).

96 Professor Ernst Freund of The University of Chicago Law School anticipated this approach a decade before Masses. See Ernst Freund, The Police Power: Public Policy and Constitutional Rights $\$ \S 474-77$ at 508-12 (Callaghan 1904) (citing examples in Illinois and New York courts in which defendants were acquitted of seditious acts because their speech was not proven to effect incitement, and speech in the absence of effected incitement was "deemed insufficient to support a criminal prosecution").

97 Thomas A. Lawrence, Eclipse of Liberty: Civil Liberties in the United States During the First World War, 21 Wayne L Rev 33, 70 (1974) (describing the "rabid" judiciary in the FirstWorld-War era). 
conduct was found to be in violation of the prohibitions" of the Espionage Act 1917 "was ... judicial, not legislative in creation."

These judges were operating in a feverish atmosphere, not the most conducive to careful judicial reflection. Too often, they gave in to the pressures of the time and to their own fears and distaste for "disloyalty."

Not so Judge Hand. As he so presciently wrote his wife, Frances, when he was assigned the case, "there are times when the old bunk about an independent and fearless judiciary means a good deal." And so it does.

My thesis in this Essay is not that Judge Hand's "express advocacy" interpretation of the Espionage Act was necessarily "right." That is an argument for another day. ${ }^{100}$ It is, rather, more modestly, that Judge Hand was "right" in understanding that in enacting the Espionage Act of 1917 Congress did not commit the nation to the course of suppression it followed. That was a choice made by the Wilson administration and our federal judges.

Of course, Judge Hand's opinion in Masses was promptly and emphatically reversed by the court of appeals. ${ }^{101}$ Judge Hand was passed over for promotion, which went "to a more political, less distinguished" judge. ${ }^{102}$ Judge Hand reflected later that "the case cost me something, at least at the time," but "I have been very happy to do what I believe was some service to temperateness and sanity."

The circulation of The Masses dropped precipitously because without mailing privileges it was unable to reach most of its audience. A few days after the decision of the court of appeals upholding the order of the Postmaster, the government indicted seven of The

98 O'Brian, 42 Rep NY St Bar Assn at 301 (cited in note 4).

99 Gunther, Learned Hand at 155 (cited in note 26).

100 See Geoffrey R. Stone, The Origins of the "Bad Tendency" Test: Free Speech in Wartime, 2002 Sup Ct Rev (forthcoming) (arguing that Judge Hand's interpretation of the Act was more consistent with the common law of attempts than the prevailing judicial interpretation of the Act). It is also noteworthy that the amendments to the original draft of the nonmailability provision focused expressly on "matter[s] advocating or urging treason, insurrection or forcible resistance to any law of the United States." Thus, where Congress paid specific attention to this issue it adopted a formulation that tracked the express advocacy standard. Even if the prevailing judicial interpretation of the 1917 Act went well beyond the intent or expectations of Congress in suppressing dissent, Judge Hand's emphasis on express incitement was not the only alternative. Courts might, for example, have insisted on a closer connection between speech and harm, or they might have insisted on a clearer showing of specific intent to encourage unlawful conduct. Any of these approaches - focusing on express incitement, harm, or specific intent - would have been consistent with the language of the Act and the intent of Congress, without quite so broadly stifling dissent.

101 Masses Publishing Co v Patten, 246 F 24 (2d Cir 1917).

102 Gunther, Learned Hand at 161 (cited in note 26) (noting that Judge Martin T. Manton received a vacant spot on the Second Circuit).

103 Id (quoting a letter from Judge Hand to C.C. Burlingham). 
Masses's editors and staff for conspiracy to violate the Espionage Act. By the end of the year, The Masses was out of business.

104 The indictment of the editors and staff of The Masses was encouraged by the court of appeals. See Court Finds Masses Unfit to be Mailed, NY Times 10 (Nov 3, 1917) (noting that the Second Circuit's decision "clears the way for any criminal action the Department of Justice may wish to take"); Seditious Editors Now Fear Prison, NY Times 17 (Nov 4, 1917) (noting that the Masses decision spread "[g]reat alarm ... among publishers and editors"). Immediately after the court of appeals "sustained the action of the postal authority," the "government prosecutor laid the facts before the Grand Jury." Indicts The Masses and 7 of its Staff, NY Times 4 (Nov 20,1917). Among those indicted were Max Eastman, John Reed, Josephine Bell, and Henry Glinkerkamp. See id. The Masses defendants were tried twice. Each trial ended in a hung jury. See Gunther, Learned Hand at 152 (cited in note 26) (detailing the ultimate demise of The Masses). 